\title{
A STUDY OF MICROINCLUSIONS IN MINERALS OF SPANISH LAMPROITES.
}

\section{Solovova; A. Gimis; L. Kogarko and I. Ryabchikov.}

In order to estimate thermodinamic conditions and melt compositions ol Spanish lamproltes, microinclusions in olivine, ciinopyroxene, sanidine, apatite, phlogoplte, and calcite have peen studied. Among daughter minerals in melt incusions 01 , Phi, San and F-Ap were determined. Unusual compositions of daugnter minerais correspond to unusual chemistry of lamproitic Iavas: 1.e. San contains large quant1ties of both $\mathrm{Mg}$ and $\mathrm{Fe}$, inl contains up to $8 \mathrm{wt} . \% \mathrm{TiO}_{2}$ and more then $1 \mathrm{wt} . \% \mathrm{~F}$.

Homogenization temperature of melt inclusions in the most magnesian oifvine is $1250^{\circ} \mathrm{C}$ and decreases w1th increasing of $\bar{X}_{\text {Fe }}$ OI OI to $1050^{\circ} \mathrm{O}$. Average composition of nomogenized melt inclusions in the earliest ollvine studied $\left(\mathrm{X}_{\bar{F}}=0.08\right)$ is following: (wt.\%) $\mathrm{SlO}_{2}, 52.1, \mathrm{THO}_{2} 0.2, \mathrm{Al}_{2} \mathrm{O}_{3} 11.6$, $\mathrm{FeO}(\mathrm{t}) 3.9, \mathrm{MgO} 5.4$, CaO 0.1, BaO 0.3, $\mathrm{Na}_{2} \mathrm{O} 0.9, \mathrm{~K}_{2} \mathrm{O} 13.5, \mathrm{P}_{2} \mathrm{O}_{5}$ 3.4, F 0.9, CI 0.3. The composition of the late-stage melts is represented by primary melt inclusion in calcite: $\mathrm{S}_{10} \mathrm{I}_{2} 64.7$, $\mathrm{THO}_{2}$ 0.8, $\mathrm{Al}_{2} \mathrm{O}_{3}$ 17.8, $\mathrm{FeO}(\mathrm{t})$ 1.1, $\mathrm{MgO} 0.2, \mathrm{CaO} 2.5, \mathrm{Na}_{2} \mathrm{O} 0.3$, $x_{2}, 0$ 4.6. Water content of this evolved melt is about 8 wt.\%. For more primitive meits a value 4 wt.\% have been estimated.

Filuid inciusions are mostly partially decrepitated iow-dense 60 . Sometimes salt crystalls on the walls of fluid inciusions are visibie, proving high halogen concentrations in the IIluid.

Daughter sanidine in melt inclusions contains appreciable amount of $\mathrm{F}^{3+}$ which is characteristic of high oxygen fugacity. un the other hand Ilquid immiscibility detected in residual giasses is possible only under relatively reduced conditions. This our data confirm highly variable oxygen fugacity during iamproite crystallization wich was advocated by Venturelli et al. (1988).

Un the basis of our data we propose a model of primary meit formation by the melting of Phl-bearing Iherzolite at relativeiy low pressures. 